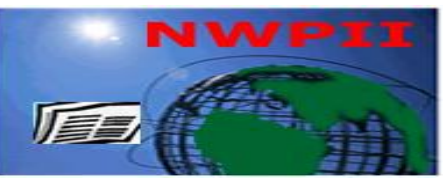

American Journal of Biomedical Sciences

ISSN: 1937-9080

nwpii.com/ajbms

\title{
The Effects of Diazepam on Selected Blood Enzymes Activity and Prostate Specific Antigen of Adult Male Wistar Rats
}

\author{
Felicia Nmeazi Okwakpam, Stephen. I. Omeodu and Augustine A. Uwakwe
}

Department of Biochemistry, Faculty of Science, University of Port Harcourt, Nigeria

"Corresponding Author

Felicia Nmeazi Okwakpam

Department of Biochemistry

Faculty of Science

University of Port Harcourt

Nigeria

Email: feliciaokwakpam@yahoo.com

Phone:+2348033412609

Received: 05 April 2018; | Revised:12 July 2018; | Accepted:01 September 2018

\begin{abstract}
This work investigated the possible effects of Diazepam on selected metabolic enzymes of adult male wistar rats liver and cardiac biomarkers. A total of sixty adult healthy male wistar rats were used and divided into five groups of twelve rats each. Animals were divided into different groups and different doses were administered to the various groups. Drugs were administered orally by intubation. Results showed that daily administration of diazepam significantly $(\mathrm{p} \leqslant 0.05)$ elevated the liver biomarkers and cardiac biomarker of all test groups when compared with the control. There was no significant change in the PSA activity of the test groups. Histological analysis of the liver revealed no pathological changes in all test groups at the end of week 1 and 2. Mild reversible pathological changes such as mild sinusoidal dilation, inflammation and degenerative changes were observed in groups 4 and 5 that received higher doses at the end of week 3 and 4, while the other groups that received lower doses of the drug maintained normal histology. The findings from this study suggest that short term administration of diazepam may not compromise PSA levels. Though the levels of liver biomarkers such as ALT, AST, ALP and LDH were significantly affected, liver histopathology showed mild reversible changes.
\end{abstract}

Keywords: Diazepam, Liver biomarkers, Cardiac biomarker, Metabolic enzymes, Histology

\section{Introduction}

Drugs are chemical substances that form the cornerstone of therapy in human diseases. They are generally given for prevention, control or cure of diseases. Most drugs act by interacting with a cellular component called receptor ${ }^{[1]}$. The efficacy of a drug is measured by the degree of effect it is able to generate at a receptor site. Drugs that 
produce useful therapeutic effect may also produce unwanted or toxic effects ${ }^{[2]}$.

Diazepam has been reported to be effective in treating problems such as acute and chronic convulsion, inappropriate elimination associated with anxiety, urine marking or spraying, fear aggression as well as to stimulate appetite ${ }^{[3]}$. Other therapeutic uses include muscle relaxant and sedative effects ${ }^{[4]}$. It is the most widely anticonvulsant followed by phenobarbitone and pentobarbital. Long term administration of Diazepam can lead to adverse effects in the brain which ultimately led to addiction have been widely reported in humans ${ }^{[5]}$ and animals ${ }^{[6]}$. Other adverse effects include neonatal complication in pregnancy, memory impairment, paradoxical stimulant effect, impaired motor coordination and depression [7]. Acute liver injury may be caused by a direct toxic effect of the drug or its metabolites in the liver cells, generating a dose-dependent effect, or by idiosyncratic drug reactions, which occur in experimental animals exposed to diazepam ${ }^{[8]}$.

Globally, there is stringent control on the usage of Diazepam due to the risk it possesses. For instance, the United Kingdom committee on the review of medicine (1980) recommended the use of Diazepam for 2-4 weeks at low dosage. Furthermore, statistics have shown that globally, the use of benzodiazepines (diazepam) for non-medical purposes is on the increase ${ }^{[9]}$. This poses a public health threat especially in Nigeria where selfmedication is on the high side and many are ignorant of the adverse effects of diazepam on body tissues.

Despite the increasing use, limited information however exist on the effect of diazepam on metabolic enzymes such as alanine aminotransferase (ALT), aspartate aminotransferase (AST), alkaline phosphatase (ALP), lactate dehydrogenase $(\mathrm{LDH})$, creatine kinase $(\mathrm{CK})$ and prostate specific antigen (PSA). Alteration of these enzymes is an indication of cellular changes associated with toxicity of diazepam on the specific tissues. The aim of this study was to investigate the effects of diazepam on ALT, AST, ALP, LDH (biochemical markers of the liver), CK (cardiac marker), PSA (prostate cancer marker) in serum as a function of diazepam activity.

\section{Materials and Methods}

\subsection{Experimental Animals}

Sixty adult male wistar rats weighing $100 \mathrm{~g}-$ $110 \mathrm{~g}$ obtained from appreciably healthy rats from the animal house, department of biochemistry, University of Port Harcourt were used to investigate the effect of diazepam on metabolic enzymes such as alanine aminotransferase (ALT), aspartate aminotransferase (AST), alkaline phosphatase (ALP), lactate dehydrogenase (LDH), creatine kinase (CK), prostate specific antigen (PSA). Acclimatization was carried out for one week prior to commencement of the study. The rats were kept in well ventilated cages and fed with commercial growers mash, manufactured by Top Feeds Ltd, Sapele, Delta State, Nigeria. Water and feed were administered ad libitum.

\subsection{Experimental Protocol}

The sixty male wistar rats used for this study were randomly allocated to five groups consisting of twelve rats each. The first group was used as the control while the other groups were administered different doses of diazepam. The study lasted for four weeks. The groupings are as follows.

Group 1 rats (control) were administered distilled water and comprised 12 adult male wistar rats

Group 2 rats were administered $0.0016 \mathrm{mg} / \mathrm{kg}$ diazepam and comprised 12 adult male wistar rats

Group 3 rats were administered $0.0026 \mathrm{mg} / \mathrm{kg}$ diazepam and comprised 12 adult male wistar rats.

Group 4 rats were administered $0.0036 \mathrm{mg} / \mathrm{kg}$ diazepam and comprised 12 adult male wistar rats.

Group 5 rats were administered $0.0046 \mathrm{mg} / \mathrm{kg}$ diazepam and comprised 12 adult male wistar rats.

\subsection{Drug Administration}

Diazepam tablets from F. Hoffmann-La Roche Ltd., Basel, Switzerland by Roche S.p.A Milan production site, Italy were used for this study. The drugs were orally administered to the rats at varying doses $(0.0016-0.0046 \mathrm{mg} / \mathrm{kg}$ body weight $)$ one daily. 


\subsection{Sample Collection/ Preparation}

Blood samples were collected from the rats in four phases.

Phase 1: This was carried out one week after acclimatization

Phase 2: This was carried out two weeks after acclimatization

Phase 3: This was carried out three weeks after acclimatization

Phase 4: This was carried out four weeks after acclimatization

At the end of each phase, three rats from each group were euthanized under chloroform vapor and dissected. Whole blood sample was collected from the heart cavity with syringe into plain sample bottles; the liver tissues were taken surgically and kept in a plain bottle containing $10 \%$ formalin for preservation prior to the histopathological processing. The bottles containing the blood samples were allowed to stand for one hour to enable the blood to clot and therefore centrifuged at $3,000 \mathrm{~g}$ for 10 minutes. The serum obtained was used for biochemical assay. The samples were then analyzed following the different protocols for each enzyme.

\subsection{Biochemical Tests}

The serum obtained was used to assess aspartate aminotransferase (AST; randox test kits) ${ }^{[10]}$; alanine aminotransfrase (ALT; randox test kits) [11]; alkaline phosphatase (ALP; randox test kits) ${ }^{[12]}$; creatine kinase (CK; randox test kits) ${ }^{[13]}$ and prostate specific antigen (PSA; Accubind Elisa microwells kits) ${ }^{[14]}$ activities according to the manufacturer' $s$ instructions.

\subsection{Histological Analysis}

Microscopic observation of the liver of the experimental animals was carried out as described by ${ }^{[15]}$.

\subsection{Data Analysis}

The data generated were analyzed for statistical differences between the different groups treated with different concentration of the drugs respectively as well as statistical differences by means of one way ANOVA using SPSS software version 20. Differences were considered significant when $\mathrm{p}<0.05$. Data were presented as mean \pm S.E.M (standard error of mean).

\section{Results}

Table 1: Effect of diazepam on rat serum Alanine aminotransferase (ALT) activity of adult male wistar rats SerumALT Concentration [IU /L]

\begin{tabular}{|c|c|c|c|c|}
\hline GROUP & WEEK 1 & WEEK 2 & WEEK 3 & WEEK 4 \\
\hline 1(Control) & $7.00 \pm 0.58^{\mathrm{a}}$ & $7.33 \pm 0.33^{\mathrm{a}}$ & $7.00 \pm 0.58^{\mathrm{a}}$ & $6.67 \pm 0.58^{\mathrm{a}}$ \\
\hline 2 & $12.50 \pm 0.29^{b}$ & $13.00 \pm 0.58^{b}$ & $12.50 \pm 0.29^{b}$ & $13.17 \pm 0.44^{b}$ \\
\hline 3 & $16.00 \pm 0.00^{\mathrm{b}}$ & $15.00 \pm 0.58^{\mathrm{b}}$ & $14.50 \pm 0.87^{\mathrm{b}, \mathrm{c}}$ & $14.00 \pm 0.00^{\mathrm{b}, \mathrm{c}}$ \\
\hline 4 & $19.50 \pm 0.87^{\mathrm{b}, \mathrm{c}}$ & $17.00 \pm 0.58^{b}$ & $15.00 \pm 0.58^{b, c}$ & $15.00 \pm 0.58^{\mathrm{b}, \mathrm{c}}$ \\
\hline 5 & $21.00 \pm 0.58^{c}$ & $22.50 \pm 0.87^{c}$ & $16.00 \pm 0.87^{\mathrm{c}}$ & $16.33 \pm 0.88^{c}$ \\
\hline
\end{tabular}

Values are presented as mean $\pm \mathrm{SEM}, \mathrm{n}=3$ per group. Values on the same column with different superscript letters (a.b,c) differ significantly at $\mathrm{p}<0.05$.

Results in table 1 showed that variations were recorded in enzyme activities among the various groups. Daily administration of diazepam significantly $(\mathrm{p}<0.05)$ elevated serum alanine aminotransferase activity values when group 2 $(0.0016 \mathrm{mg} / \mathrm{kg}$ diazepam), group $3(0.0026 \mathrm{mg} / \mathrm{kg}$ 
diazepam), group $4(0.0036 \mathrm{mg} / \mathrm{kg}$ diazepam $)$ and group $5(0.0046 \mathrm{mg} / \mathrm{kg}$ diazepam) were compared with group 1 (control rats) from week one to week four. The control (group 1) at week one recorded an ALT activity value of $7.00 \pm 0.58 \mathrm{IU} / \mathrm{L}$ while groups 2, 3, 4 and 5 had ALT activity values of
$12.50 \pm 0.29,16.00 \pm 0.00,19.50 \pm 0.87$ and 21.00 $\pm 0.58 \mathrm{IU} / \mathrm{L}$ respectively. At the end of week four, the control (group 1) had serum ALT activity values of $6.67 \pm 0.58 \mathrm{IU} / \mathrm{L}$ while groups $2,3,4$ and $5 \mathrm{had}$ ALT activity values of $13.17 \pm 0.44,14.00 \pm 0.00$ $15.00 \pm 0.58$ and $16.33 \pm 0.88 \mathrm{IU} / \mathrm{L}$ respectively.

Table 2: Effect of diazepam on rat serum aspartate aminotransferase (AST) activity of adult male wistar rats Serum AST concentration (IU/L)

\begin{tabular}{|c|c|c|c|c|}
\hline GROUP & WEEK 1 & WEEK 2 & WEEK 3 & WEEK 4 \\
\hline 1 (Control) & $7.00 \pm 0.58^{\mathrm{a}}$ & $8.66 \pm 0.88^{\mathrm{a}}$ & $8.50 \pm 0.58^{a}$ & $8.66 \pm 0.88^{a}$ \\
\hline 2 & $12.50 \pm 0.29^{b}$ & $14.50 \pm 0.87^{b c}$ & $14.00 \pm 0.00^{\mathrm{b}}$ & $12.67 \pm 0.58^{b}$ \\
\hline 3 & $13.00 \pm 0.58^{b}$ & $16.50 \pm 0.87^{b c}$ & $16.50 \pm 0.50^{\mathrm{bc}}$ & $13.00 \pm 0.00^{\mathrm{b}}$ \\
\hline 4 & $16.50 \pm 0.29^{b, c}$ & $18.00 \pm 1.15^{b c}$ & $17.00 \pm 0.58^{\mathrm{bc}}$ & $15.00 \pm 0.58^{b c}$ \\
\hline 5 & $17.00 \pm 0.58^{c}$ & $19.00 \pm 0.58^{c}$ & $18.00 \pm 0.58^{c}$ & $17.00 \pm 0.58^{c}$ \\
\hline
\end{tabular}

Values are presented as mean \pm SEM, $n=3$ per group. Values on the same column with different superscript letters $(a, b, c)$ differ significantly at $\mathrm{p}<0.05$.

Table 3: Effect of diazepam on rat serum alkaline phosphatase (ALP) activity of adult male wistar rats Serum ALP concentration (IU/L)

\begin{tabular}{ccccc}
\hline GROUP & WEEK1 & WEEK 2 & WEEK 3 & WEEK 4 \\
\hline 1 & $114.00 \pm 0.58^{\mathrm{a}}$ & $121.33 \pm 0.88^{\mathrm{a}}$ & $123.00 \pm 1.15^{\mathrm{a}}$ & $110.00 \pm 0.58^{\mathrm{a}}$ \\
2 & $117.50 \pm 1.44^{\mathrm{b}}$ & $183.00 \pm 1.73^{\mathrm{b}}$ & $155.00 \pm 1.73^{\mathrm{b}}$ & $151.00 \pm 4.04^{\mathrm{b}}$ \\
3 & $196.00 \pm 2.31^{\mathrm{bc}}$ & $195.00 \pm 1.73^{\mathrm{bc}}$ & $168.00 \pm 2.31^{\mathrm{b}}$ & $158.00 \pm 1.15^{\mathrm{b}}$ \\
& $200.00 \pm 0.00^{\mathrm{bc}}$ & $200.00 \pm 2.89^{\mathrm{bc}}$ & $176.00 \pm 3.46^{\mathrm{b}}$ & $169.50 \pm 2.59^{\mathrm{b}}$ \\
5 & $220.00 \pm 11.54^{\mathrm{c}}$ & $205.00 \pm 2.89^{\mathrm{c}}$ & $198.00 \pm 1.15^{\mathrm{c}}$ & $185.00 \pm 2.89^{\mathrm{c}}$
\end{tabular}

Values are presented as mean \pm SEM, $n=3$ per group. Values on the same column with different superscript letters $(\mathrm{a}, \mathrm{b}, \mathrm{c})$ differ significantly at $\mathrm{p}<0.05$.

Results as presented in table 2 showed that at week one, the control (group 1) recorded a serum AST activity values of $7.00 \pm 0.58 \mathrm{IU} / \mathrm{L}$ while the other groups recorded $12.50 \pm 0.29,13.00 \pm 0.58$, $16.50 \pm 0.29$ and $17.00 \pm 0.58 \mathrm{IU} / \mathrm{L}$ for groups 2,3 , 4 and 5 AST activity values respectively. It was also observed that at the end of the study, the control (group 1) recorded a serum AST activity value of $8.66 \pm 0.88 \mathrm{IU} / \mathrm{L}$. The serum activity of AST for groups $2,3,4$ and 5 were $12.50 \pm 0.29,13.00 \pm 0.58$, $16.00 \pm 0.29$ and $17.00 \pm 0.58 \mathrm{IU} / \mathrm{L}$ respectively. 
Results in table 3 revealed that there were differences in enzyme activities among the different test groups. Diazepam administration significantly elevated serum alkaline phosphatase activity when groups 2, 3, 4 and 5 were compared with the control (group 1). The study also showed that at week one, the control (group 1) recorded a serum ALP activity value of $114.00 \pm 0.58 \mathrm{IU} / \mathrm{L}$ while at week four, the serum ALP activity was $110.00 \pm 0.58 \mathrm{IU} / \mathrm{L}$. Furthermore, the ALP activity values of $117.50 \pm$ $1.44 \mathrm{IU} / \mathrm{L}, 196.00 \pm 2.31 \mathrm{IU} / \mathrm{L}, 200.00 \pm 0.00 \mathrm{IU} / \mathrm{L}$ and $220.00 \pm 11.54 \mathrm{IU} / \mathrm{L} ; 151.00 \pm 4.04,158.00 \pm$ $1.15,169.50 \pm 2.59$ and $185.00 \pm 2.89 \mathrm{IU} / \mathrm{L}$ were recorded for groups 2, 3, 4 and 5 for weeks one and four respectively.

Table 4: Effect of diazepam on rat serum lactate dehydrogenase (LDH) activity of adult male wistar rats

\begin{tabular}{|c|c|c|c|c|}
\hline GROUP & WEEK 1 & WEEK 2 & WEEK 3 & WEEK 4 \\
\hline 1 (Control) & $177.00 \pm 0.58^{a}$ & $189.00 \pm 0.88^{\mathrm{a}}$ & $174.00 \pm 1.54^{\mathrm{a}}$ & $161.33 \pm 0.88^{a}$ \\
\hline 2 & $273.00 \pm 13.27^{b}$ & $256.00 \pm 2.31^{b}$ & $252.00 \pm 18.48^{b}$ & $225.50 \pm 8.95^{b}$ \\
\hline 3 & $311.00 \pm 6.35^{b}$ & $287.00 \pm 4.04^{b}$ & $277.00 \pm 4.04^{b}$ & $257.50 \pm 4.33^{b}$ \\
\hline 4 & $315.00 \pm 5.77^{b c}$ & $304.00 \pm 3.46^{\mathrm{bc}}$ & $289.00 \pm 3.17^{b c}$ & $285.00 \pm 2.88^{b c}$ \\
\hline 5 & $382.50 \pm 4.33^{\mathrm{c}}$ & $310.00 \pm 5.77^{\mathrm{c}}$ & $291.00 \pm 6.08^{c}$ & $287.00 \pm 7.50^{\mathrm{c}}$ \\
\hline
\end{tabular}

Values are presented as mean \pm SEM, $n=3$ per group. Values on the same column with different superscript letters $(a, b, c)$ differ significantly at $\mathrm{p}<0.05$.

There were marked variations recorded in lactate dehydrogenase (LDH) enzyme activity as shown in table 4. Daily diazepam administration significantly $(p<0.05)$ elevated the serum lactate dehydrogenase activity when groups $2,3,4$ and 5 were compared with the control (group 1) for week one to four. The study also showed that at week one, the control (group 1) recorded a serum LDH activity values of $177.00 \pm 0.58 \mathrm{IU} / \mathrm{L}$ while at week four, the serum LDH activity values was $161.33 \pm 0.88$ IU/L. Furthermore, the LDH activity values of $273.00 \pm 13.27$ and $225.50 \pm 8.95 \mathrm{IU} / \mathrm{L} ; 311.00 \pm$ 6.35 and $257.50 \pm 4.33 \mathrm{IU} / \mathrm{L} ; 315.00 .50 \pm 5.77$ and $285.00 \pm 2.88 \mathrm{IU} / \mathrm{L} ; 382.50 \pm 4.33$ and $287.00 \pm$ $7.50 \mathrm{IU} / \mathrm{L}$ were recorded for groups $2,3,4$ and 5 for weeks one and four respectively.

Table 5: Effect of diazepam on rat serum creatine kinase (CK) activity of adult male wistar rats

\begin{tabular}{|c|c|c|c|c|}
\hline GROUP & WEEK 1 & WEEK 2 & WEEK 3 & WEEK 4 \\
\hline 1 (Control) & $36.00 \pm 0.58^{a}$ & $32.00 \pm 0.78^{\mathrm{a}}$ & $31.00 \pm 0.58^{\mathrm{a}}$ & $31.00 \pm 0.58^{\mathrm{a}}$ \\
\hline 2 & $40.00 \pm 0.86^{b}$ & $43.00 \pm 0.58^{b}$ & $42.00 \pm 1.54^{b}$ & $38.00 \pm 1.54^{\mathrm{b}}$ \\
\hline 3 & $44.50 \pm 0.86^{\mathrm{b}}$ & $44.00 \pm 1.15^{b}$ & $42.00 \pm 0.58^{b}$ & $40.00 \pm 0.89^{b}$ \\
\hline 4 & $51.00 \pm 0.58^{b c}$ & $52.50 \pm 2.60^{b c}$ & $45.00 \pm 0.58^{\mathrm{bc}}$ & $46.00 \pm 1.15^{\mathrm{bc}}$ \\
\hline 5 & $52.00 \pm 2.30^{\mathrm{c}}$ & $56.00 \pm 2.31^{\mathrm{c}}$ & $48.00 \pm 0.58^{c}$ & $48.00 \pm 0.58^{c}$ \\
\hline
\end{tabular}

Values are presented as mean \pm SEM, $n=3$ per group. Values on the same column with different superscript letters $(\mathrm{a}, \mathrm{b}, \mathrm{c})$ differ significantly at $\mathrm{p}<0.05$. 
Results in table 5 showed that there were differences in enzyme activities among the different test groups. Diazepam administration significantly elevated serum creatine kinase activity when groups 2, 3, 4 and 5 were compared with the control group. The study also showed that at week one, the control group recorded a serum CK activity of $36.00 \pm 0.58$ while at week four, the serum $\mathrm{CK}$ activity was $31.00 \pm 0.58 \mathrm{IU} / \mathrm{L}$. Furthermore, the CK activity values of $40.00 \pm 0.86$ and $38.00 \pm 1.54 \mathrm{IU} / \mathrm{L} ; 44.50$ \pm 0.86 and $40.00 \pm 0.89 \mathrm{IU} / \mathrm{L} ; 51.00 \pm 0.58$ and $46.00 \pm 1.15 \mathrm{IU} / \mathrm{L} ; 52.00 \pm 2.30 \mathrm{IU} / \mathrm{L}$ and $48.00 \pm$ $0.58 \mathrm{IU} / \mathrm{L}$ were recorded for groups $2,3,4$ and 5 for weeks one and four respectively.

Table 6: Effect of diazepam on rat serum prostate specific antigen (PSA) activity (ng/ml) of adult male wistar rats

\begin{tabular}{ccccc}
\hline & WEEK1 & WEEK 2 & WEEK 3 & WEEK 4 \\
\hline $1($ Control $)$ & $0.27 \pm 0.03^{\mathrm{a}}$ & $0.37 \pm 0.0 .3^{\mathrm{a}}$ & $0.37 \pm 0.03^{\mathrm{a}}$ & $0.37 \pm 0.03^{\mathrm{a}}$ \\
2 & $0.27 \pm 0.07^{\mathrm{a}}$ & $0.40 \pm 0.06^{\mathrm{a}}$ & $0.30 \pm 0.06^{\mathrm{a}}$ & $0.40 \pm 0.00^{\mathrm{a}}$ \\
3 & $0.30 \pm 0.10^{\mathrm{a}}$ & $0.30 \pm 0.00^{\mathrm{a}}$ & $0.40 \pm 0.00^{\mathrm{a}}$ & $0.33 \pm 0.03^{\mathrm{a}}$ \\
4 & $0.27 \pm 0.03^{\mathrm{a}}$ & $0.27 \pm 0.07^{\mathrm{a}}$ & $0.37 \pm 0.09^{\mathrm{a}}$ & $0.40 \pm 0.06^{\mathrm{a}}$ \\
5 & $0.27 \pm 0.07^{\mathrm{a}}$ & $0.27 \pm 0.07^{\mathrm{a}}$ & $0.37 \pm 0.03^{\mathrm{a}}$ & $0.37 \pm 0.07^{\mathrm{a}}$
\end{tabular}

Values are presented as mean $\pm \mathrm{SEM}, \mathrm{n}=3$ per group. Values on the same column with different superscript letters $(a, b, c)$ differ significantly at $p<0.05$.

There were significant differences recorded in prostate specific antigen (PSA) enzyme activity as shown in table 6. Diazepam administration significantly $(\mathrm{p}<0.05)$ elevated the serum PSA activity when groups 2, 3, 4 and 5 were compared with the control group for week one to four. The study also showed that at week one, the control (group 1) recorded a serum PSA activity of $0.27 \pm$
$0.03 \mathrm{ng} / \mathrm{ml}$ while at week four, the serum PSA activity value was $0.37 \pm 0.03 \mathrm{ng} / \mathrm{ml}$. Furthermore, the PSA activity values of $0.27 \pm 0.07$ and $0.40 \pm$ $0.00 \mathrm{ng} / \mathrm{ml} ; 0.30 \pm 0.10$ and $0.33 \pm 0.03 \mathrm{ng} / \mathrm{ml} ; 0.27$ \pm 0.03 and $0.40 \pm 0.06 \mathrm{ng} / \mathrm{ml} ; 0.27 \pm 0.07$ and 0.37 $\pm 0.07 \mathrm{ng} / \mathrm{ml}$ values were recorded for groups 2,3 , 4 and 5 for weeks one and four respectively.

\section{Histology results}

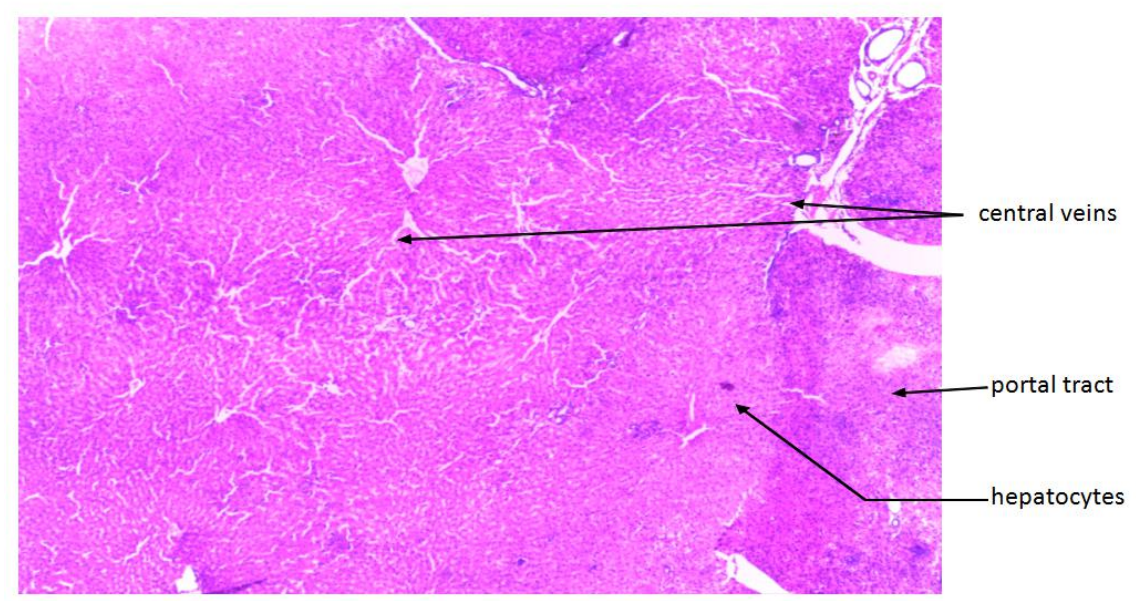

Figure 1:Photomicrograph of histology of liver of control rat (H\&E mag. X 200) shows normal histology 


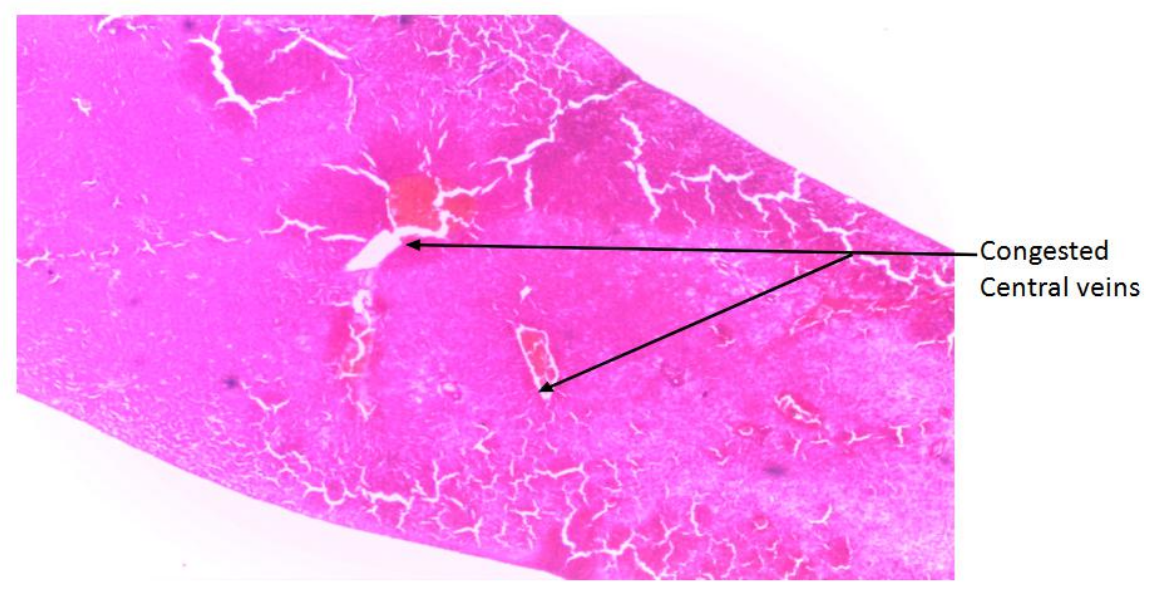

Figure 2:Photomicrograph of histology of liver of male adult rats after week three (H\&E mag. X 200)

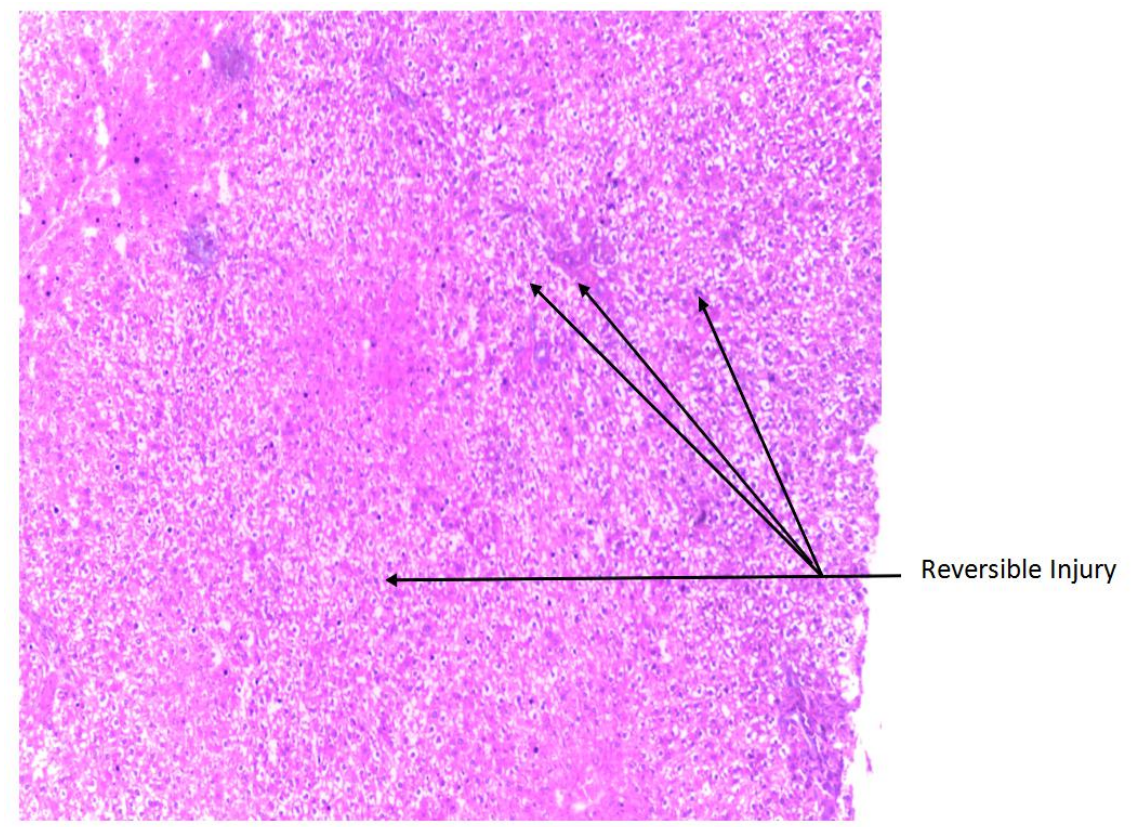

Figure 3:Photomicrograph of histology of liver of male wistar rat after week four(H\&E mag. X 200) shows vacuolar change in hepatocyte (Reversible injury)

\section{Discussion}

The Biochemical studies showed that daily administration of diazepam significantly $(p<0.05)$ elevated serum activity of alanine aminotranferase in all test groups when compared with the control group. This finding is in support of the study of ${ }^{[16]}$ and ${ }^{[17]}$ whose results showed significant increase in the serum activity of ALT in rats and cats in the administration of diazepam. The largest amount of ALT is in the cytosol of hepatic parenchymal cells ${ }^{[18]}$. Hepatocellular damage resulting to disruption of plasma membrane allows leakage of ALT into the blood stream ${ }^{[19]}$. Due to its high concentration in the liver, serum ALT is one of the most universal markers for hepatic injury across species. However, [20] suggested that increased hepatic synthesis of ALT by some hepatoxicants such as drugs is also a source of increase of serum activity as seen in this study. Also an elevated serum activity of ALT could also be attributed to the report that in rat cortisols enhances hepatic activities of ALT ${ }^{[21]}$. 
The increase in the activity of AST was dosedependent with high doses having more serum AST activity than the lower doses. This finding supports the findings of ${ }^{[16]}$ and ${ }^{[17]}$ whose results indicated considerable increase in the serum activity of ALT in rats and cats respectively in the administration of diazepam. A high level of AST in the serum is an indicator of mitochondrial damage in mostly the centrilobular regions of the liver. This region is sensitive to toxic \& hypoxic substances ${ }^{[22]}$. Although AST is also available in other tissues such as brain, kidney, heart and muscle, elevated AST and ALT are considered as important markers of hepatic injury.

ALP is mostly present in the cells which line the bile ducts in the liver and in lesser amount in other parts such as bone, placenta, kidney and intestine. This makes it primarily a biomarker of hepatobilary effects [23]. Result obtained in this study agrees with the work of ${ }^{[17]}$ whose results showed that continuous oral administration of diazepam considerably elevated serum concentration of ALT, AST \& ALP but differs from the works of ${ }^{[16]}$ whose results showed that chronic administration of diazepam caused significant reduction in ALP activity. These differences could be attributed to the fact that in long term administration, the effect of diazepam begins to wear off. The results obtained in the study supports the claim that elevated ALT, AST and modest increase in ALP is an indication of hepatocellular injury ${ }^{[23]}$.

Evaluation of serum level of $\mathrm{LDH}$ is an essential tool in clinical analysis as it helps in detection of hepatocellular necrosis. Results obtained in this study showed that administration of diazepam significantly $(\mathrm{p} \leqslant 0.05)$ increase serum $\mathrm{LDH}$ levels in all test groups when compared to control from week 1 to 4 . This result supports the study carried out by ${ }^{[17]}$ whose findings showed that repeated oral administration of diazepam significantly elevated LDH. Although elevated LDH levels could also be as a result of its release from damaged cells from various part of the body as well as the liver due to exposure to drugs, elevated LDH levels together with higher activities of ALT, AST and ALP as an indication that the increase is of hepatic origin ${ }^{[23]}$.
Creatine kinase $(\mathrm{CK})$ is an important enzyme responsible for the generation of adenosine triphosphate (ATP) for high ATP requiring cells. The administration of diazepam as shown from results in this study significantly elevated serum level of CK in all test groups when compared to the control. Known causes of elevated CK such as delirium, malignant neuroleptic trauma and intra muscular infections were not the case in this study. The increase in the serum activity of creatine kinase could be attributed to its net synthesis following exposure to these drugs. This work agrees with the work of ${ }^{[24]}$ whose findings showed increased level of $\mathrm{CK}$ after post myocardial infarction following the administration of diazepam. This increase in serum activity of $\mathrm{CK}$ should be considered when evaluating outcome of persons exposed to oral administration of diazepam in order not to make an erroneous conclusion.

Prostate specific antigen (PSA) is a protein produced in the prostate. It is specific and sensitive for the diagnosis and management of prostatic carcinoma, a common male tumor. Prostate carcinoma is now most frequently diagnosed following the detection of elevated PSA. Therefore factors that alter PSA level can potentially compromise the identification of prostate cancer. From this study, it was observed that the serum PSA level was not altered in all test groups when compared to control group from week 1 to week 4 following administration. Therefore, diazepam administration does not compromise the role of PSA in early detection of prostate cancer and subsequent reduction in prostate cancer-specific mortality. It is therefore safe for normal and persons with prostate cancer.

Evaluation of the hepatic tissues of the control group and test groups at week one as well as the control (group 1) of weeks 2 to 4 showed no damage to hepatocyte following varying dose of diazepam. Conversely, the histopathological investigation of the liver of the test (groups 2-5) from week 3 to week 4 showed reversible changes such as mild periportal inflammation, mild vascular change and congested central vein. The results obtained from the histopathological investigation of the liver revealed no serious histopathological change in the liver. All changes observed were mild and reversible. This implies that the increase in the 
serum levels of the metabolic enzymes (ALT, AST, ALP, and LDH) used in assessment of hepatic damage was not mainly due to membrane leakage caused by hepatic damage but as a result of increase in synthesis of these hepatic enzymes following the administration of diazepam ${ }^{[21]}$. The result obtain in this study is in support of works of ${ }^{[25]}$ whose result showed increase in ALT and AST for more than twenty weeks in the absence of specific histopathology following the administration of anticonvulsants in humans, works of ${ }^{[26]}$ where administration of antiepileptic drugs to rats exhibited high levels of ALT, AST and GGT without any indication of hepatocellular injury and the research of ${ }^{[27]}$ whose result showed ALT levels up to three times and AST levels up to two times following the administration of antiepileptic drugs without any significant changes in the histopathology of the liver. The increase in ALT and AST were attributed to enzyme induction by the drugs.

In conclusion, the short term administration of diazepam did not significantly affect prostate specific antigen (PSA) level suggesting that the drug do not compromise the possible detection of prostate cancer. Also, the activities of alanine aminotransferase, aspartate aminotransferase, alkaline phosphatase and lactate dehydrogenase where significantly elevated while the histopathological examination showed mild and hepatocellular damage. Therefore this observation should keep all consumers of the drug on alert on any sign of liver disease.

\section{References}

1 Ariens, F.J. Receptors from friction to fact. Trends Pharmacology, 1979, SCI. 1:11-15.

2 Woolf TF, Jordan RA. Basic concepts in drug metabolism: Part I. J Clin Pharmacol 1987; 27(1): 15-17 [PMID: 3316300]

3 Maddison, J. E., Page, S. W. and Church, D. B. Small Animal Clinical Pharmacology. 1st Edn., Elsevier Health Sciences, London, ISBN: 07020255739, 2002, Pp: 575.

4 Hollister LE, Muller-Oerlinghausen B, Rickels K, Shader RI. Clinical uses of benzodiazepines. J Clin Psychopharmacol 1993; 13(6 Suppl 1): 1S-169S [PMID: 7905883]
5 Ashton $\mathrm{H}$. The diagnosis and management of benzodiazepine dependence. Curr Opin Psychiatry 2005; 18(3): 249-255 DOI: 10.1097/01.yco.0000165594.60434.84

6 Nutt DJ, Malizia AL. New insights into the role of the GABA(A)-benzodiazepine receptor in psychiatric disorder. Br J Psychiatry 2001; 179: 390-396 [PMID: 11689393]

7 Ashton , H. Benzodiazepine Dependence, Adverse Syndromes and Psychiatric Drugs. Oxford University Press, 2004, Pp. 239-260.

8 Lappin, M. R. Feline Internal Medicine Secrets. 4th Edn., Elsevier Health Sciences, Philadelphia, ISBN-10: 1560534613, 2001, pp: 479.

9 McCabe , S. E . Correlates of Nonmedical Use of Prescription Benzodiazepine Anxiolytics: Results from a National Survey of U. S. College Students. Drugs and Alcohol Dependence, 2005, 79: 53-62.

10 Reitman S, Frankel S. A colorimetric method for the determination of serum glutamic oxalacetic and glutamic pyruvic transaminases.

Am J Clin Pathol 1957; 28(1): 56-63

11 Deutsche Gesellschaft Fur Klinishce Chemie. Determination of Alkaline Phosphatase Activity. Journal of Clinical Chemistry and Clinical Biochemistry, 1972a, 15: 255.

12 Deutsche Gesellschaft Fur Klinishce Chemie. Determination of Serum Creatine Kinase Activity. Journal of Clinical Chemistry and Clinical Biochemistry, 1972b, 15: 255.

13 Deutsche Gesellschaft Fur Klinishce Chemie. Determination of Serum Lactate Dehydrogenase Activity. Journal of Clinical Chemistry and Clinical Biochemistry, 1972c, 15: 255.

14 Christensson, A., Laurell, C. and Lilja, H. Determination of Serum Prostate Specific Antigen Activity. European Journal of Biochemistry, 1990, 194: 755-63.

15 Baker, F. S. and Silverton, R.E. Cellular Pathology In: Introduction to Medical Laboratory Technology. (7th Edn.) Oxford; Woborn, MA: Butterworth-Heinemann, 1985, Pp. 133-197.

16 Rasha, A., Tawfiq, K., Woha,N., Ezzeldein, S., El-Densharry, W. and El-Eraley, E. Enhanced Efficacy and Reduced Side Effects of 
Diazepam by Kava Combination. Journal of Advanced Research, 2014, 5(5): 587-594.

17 Mossallanejad, B., Avizeh, R. and Najafzadeh, H. Evaluation of Prophylactic and Therapeutic Effects of Silymarin on Diazepam-Induced Hepatoxicity in Cats. American Journal of Applied Sciences, 2011, 8(9): 848-853.

18 Sherman KE. Alanine aminotransferase in clinical practice. A review. Arch Intern Med 1991; 151(2): 260-265 [PMID: 1992953]

19 Hultcrantz R, Glaumann H, Lindberg G, Nilsson LH. Liver investigation in 149 asymptomatic patients with moderately elevated activities of serum aminotransferases.

Scand J Gastroenterol 1986; 21(1): 109-113 [PMID: 3952445]

20 Pappas NJ, Jr. Source of increased serum aspartate and alanine aminotransferase: cycloheximide effect on carbon tetrachloride hepatotoxicity. Clin Chim Acta 1986; 154(3): 181-189 [PMID: 3955844]

21 Amacher DE. Serum transaminase elevations as indicators of hepatic injury following the administration of drugs. Regul Toxicol Pharmacol 1998; 27(2): 119-130 [PMID: 9671567 DOI: $\underline{10.1006 / \mathrm{rtph} .1998 .1201]}$
22 Schmidt E, Schmidt FW. Progress in the enzyme diagnosis of liver disease: reality or illusion? Clin Biochem 1990; 23(5): 375-382 [PMID: 1701367]

23 Singh, A., Bhat, T. K. and Sharma, O. A Review Article: Clinical Biochemistry of Hepatoxicity. Journal of Clinical Toxicology, 2011, S4-001(1): 1-9.

24 Dixon RA, Edwards IR, Pilcher J. Diazepam in immediate post-myocardial infarct period. A double blind trial. Br Heart $\boldsymbol{J}$ 1980; 43(5): 535-540

25 Aiges HW, Daum F, Olson M, Kahn E, Teichberg S. The effects of phenobarbital and diphenylhydantoin on liver function and morphology. J Pediatr 1980; 97(1): 22-26 [PMID: 6103924]

26 Wall M, Baird-Lambert J, Buchanan N, Farrell G. Liver function tests in persons receiving anticonvulsant medications. Seizure 1992; 1(3): 187-190 [PMID: 1344766]

27 Haidukewych D, John G. Chronic valproic acid and coantiepileptic drug therapy and incidence of increases in serum liver enzymes. Ther Drug Monit 1986; 8(4): 407-410 [PMID: 3103262] 